\title{
The burden of cancer in Ethiopia, 2000-2016: analysis of evidence from the Global Burden of Disease study and Global Health Estimate
}

\section{Występowanie chorób nowotworowych w Etiopii w latach 2000-2016 - analiza danych z badań Global Burden of Disease i Global Health Estimate}

\author{
Mulugeta Shegaze ${ }^{1}$, Tadele Girum Adal², Dereje Mesfin², Tamiru Shibiru³ \\ 'Department of Public Health, School of Public Health, College of Medicine and Health Sciences, Arba Minch University, Arba Minch \\ Town, Ethiopia \\ 2Department of Public Health, College of Medicine and Health Sciences, Wolkite University, Wolkite Town, Ethiopia \\ ${ }^{3}$ Department of Internal Medicine, School of Medicine, College of Medicine and Health Sciences, Arba Minch University, Arba Minch \\ Town, Ethiopia
}

Medical Studies/Studia Medyczne 2020; 36 (2): 83-89

DOI: https://doi.org/10.5114/ms.2020.96786

Key words: mortality, causes of death, burden of cancer, disability adjusted life-years.

Słowa kluczowe: śmiertelność, przyczyny śmierci, obciążenie chorobami nowotworowymi, lata życia skorygowane o niesprawność.

\begin{abstract}
Introduction: Cancer is among the leading causes of morbidity and mortality worldwide. More than $60 \%$ of the world's total new annual cancer cases occur in Africa, Asia, and Central and South America. It is increasingly recognised as a critical public health problem in Africa. In Ethiopia, cancer accounts for about 5.8\% of total national mortality. However, lesser emphasis is given to cancer.

Aim of the research: To systematically measure the burden of cancer in Ethiopia.

Material and methods: The research used data from the Global Burden of Disease study (GBD 2016) and Global Health Estimate 2016, which originally collected the information through vital registration, verbal autopsy, surveys, reports, published scientific articles, and modelling.

Results: In 2016, cancer caused an estimated 50,913.5 (95\% CI: 36,092.1-73,018.8) deaths among all ages and both genders with a crude death rate (CDR) of 49.7/100,000 and age-standardised death rate (ASDR) of 93.5/100,000 population. It contributed to $18.5 \%$ of non-communicable disease (NCD)-related death and 7.3\% of total death, $16.9 \%$ of NCD-related ASDR and $9 \%$ of total ASDR, and $12.7 \%$ of national NCD-related disability adjusted life years lost (DALYs) and $4.3 \%$ of the national total DALYs. The number of death and DALYs from cancer increased by $47.4 \%$ and $45.1 \%$ respectively; whereas, CDR and ASDR from cancer declined by $4.2 \%$ and $9.7 \%$, respectively. The burden of cancer increased remarkably throughout the period between 2000 and 2016 .

Conclusions: The existing disease prevention strategies should incorporate non-communicable disease prevention strategies with particular emphasis for cancer screening, prevention, and care.
\end{abstract}

\section{Streszczenie}

Wprowadzenie: Nowotwory należą do głównych przyczyn zachorowalności i umieralności na świecie. Ponad 60\% całkowitej liczby nowych zachorowań na nowotwory stwierdzanych w ciągu roku występuje w Afryce, Azji oraz Ameryce Środkowej i Południowej. Choroby nowotworowe są coraz częściej uznawane za kluczowy problem zdrowia publicznego w Afryce. W Etiopii nowotwory odpowiadają za ok. 5,8\% całkowitej śmiertelności krajowej, jednak nie poświęca się im wystarczająco dużo uwagi.

Cel pracy: Systematyczny pomiar obciążenia chorobami nowotworowymi w Etiopii.

Materiał i metody: W pracy wykorzystano dane z badań Global Burden of Disease (GBD 2016) i Global Health Estimate 2016, obejmujące zarejestrowane parametry życiowe, informacje pochodzace z autopsji słownej, ankiety, raporty, opublikowane artykuły naukowe oraz modelowanie.

Wyniki: Szacuje się, że w 2016 r. nowotwory były przyczyną 50 913,5 (95\% CI: 36 092,1-73 018,8) zgonów osób obu płci we wszystkich grupach wiekowych. Surowy współczynnik umieralności (CDR) wyniósł 49,7/100 000, a współczynnik umieralności standaryzowany wg wieku (ASDR) 93,5/100 000 osób w populacji. Choroby nowotworowe przyczyniły się do 18,5\% zgonów związanych z chorobami niezakaźnymi (NCD) i 7,3\% wszystkich zgonów; 16,9\% współczynnika ASDR związanego z NCD i 9\% całkowitego ASDR oraz 12,7\% utraconych lat życia skorygowanych o niepełnosprawność (DALY) związanych 
z NCD i 4,3\% ogólnego krajowego wskaźnika DALY. Liczba zgonów i wskaźniki DALY dla nowotworów wzrosły odpowiednio o 47,4\% i 45,1\%, natomiast wskaźniki CDR i ASDR dla nowotworów zmniejszyły się odpowiednio o 4,2\% i 9,7\%. Wielkość obciążenia chorobami nowotworowymi znacząco wzrosła w latach 2000-2016.

Wnioski: Obowiązujące strategie zapobiegania chorobom powinny uwzględniać choroby niezakaźne, ze szczególnym naciskiem na badania przesiewowe, profilaktykę i opiekę.

\section{Introduction}

Cancer is a disease in which abnormal cells grow and reproduce uncontrollably and invade nearby tissues by spreading to other parts of the body through blood streams and lymphatic systems, hindering the activities of the normal cells [1-3]. Cancer incidence has increased in most countries worldwide, owing to a growing and ageing population and to an expansion of key risk factors, such as smoking, obesity, and unhealthy diet $[4,5]$.

Cancer is among the leading causes of morbidity and mortality worldwide, with approximately 18.1 million cases, 0.5 million new cases, and 9.6 million cancer-related deaths in 2018 [6]. One in five men and one in six women worldwide develop cancer during their lifetime, and one in eight men and one in 11 women die from the disease. Worldwide, the total number of people who are alive within 5 years of a cancer diagnosis, called the 5 -year prevalence, is estimated to be 43.8 million [7]. The five most common sites of cancer diagnosed for both sexes in 2018 were lung $(11.6 \%)$, breast $(11.5 \%)$, colorectal $(10.2 \%)$, prostate (7.1\%), and stomach (5\%) [6].

More than $60 \%$ of the world's total new annual cancer cases occur in Africa, Asia, and Central and South America. These regions account for $70 \%$ of global cancer deaths [6]. Furthermore, the number of new cases is expected to rise to 29.5 million by 2040 [8]. This is an alarming outlook, especially for low-income countries, where weak health systems are severely resource constrained and already overwhelmed by the large burden of communicable diseases $[1,7]$.

Cancer is increasingly recognised as a critical public health problem in Africa. While non-communicable diseases (NCDs) continue to burden African populations, it is becoming clear that non-communicable diseases also require the attention of those whose goal is to ensure the health of Africans [2, 6, 9]. Today, $60 \%$ more Africans die from cancer than succumb to malaria, and the number of cancer deaths is rising at an alarming rate [9].

According to GLOBOCAN forecasts, the number of estimated cancer deaths in 2015 was approximately 635,400 . Africa's cancer burden is projected to reach an alarming 1.4 million new cases and 1 million deaths by 2030 , simply due to the aging and growth of the population and also adoption of behaviours and lifestyles associated with economic development, such as smoking, an unhealthy diet, and physical inactivity $[8,9]$. Similarly, mortality due to cancer is increasing in Africa. Cancer mortality was estimated to be 542,000 with a diagnosis of 715,000 new cancer cases as of 2008 [10].

In Ethiopia, cancer accounts for about $5.8 \%$ of total national mortality. Although population-based data do not exist in the country except for Addis Ababa, it is estimated that the annual incidence of cancer is around 60,960 cases and the annual mortality is over 44,000 . For people under the age of 75 years, the risk of being diagnosed with cancer is $11.3 \%$ and the risk of dying from the disease is $9.4 \%$ [11]. The most prevalent cancers in Ethiopia among the adult population are breast cancer (22.2\%), cancer of the cervix (9.3\%), and colorectum (7\%). About two-thirds of reported annual cancer deaths occur among women [12]. However, the most prevalent cancers in Ethiopia among children are leukaemia, lymphoma, retinoblastoma, Wilms' tumour (nephroblastoma), and bone and soft tissue sarcomas [13].

Even though the epidemic of non-communicable disease is expected to increase, its burden is not clearly known in the country.

\section{Aim of the research}

Therefore, this study aimed to measure the burden of cancer in Ethiopia between 2000 and 2016 by using evidence from the Global Burden of Disease (GBD) Study 2016 (https://vizhub.healthdata.org/gbd-compare/) and thev Global Health Estimate (EHE) 2016 (https://www.who.int/healthinfo/global_burden_disease/en/), which will contribute to improve the health status of the population.

\section{Material and methods \\ Study area and source of data}

The burden of disease and cause of mortality has been periodically estimated by the World Health Organisation (WHO) and Institute for Health Metrics and Evaluation (IHME) since 1990. This research is based on a systematic analysis of the global burden estimates for Ethiopia. The main sources of data for this research are the WHO global health estimate database (https://www.who.int/healthinfo/global_burden_disease/en/) and the GBD study 2016 database (http:// vizhub.healthdata.org/gbd-compare/). The organisation collects, organises, and estimates disease burden in collaboration with other United Nations agencies. The estimation is particularly based on vital registries, surveys, research, and model estimations. 


\section{Operational definition}

The term disability is used broadly in disease burden analyses to refer to deviations from good or ideal health in any of the important domains of health.

Disability-adjusted life years (DALY): is a summary measure that combines time lost through premature death and time lived in states of less than optimal health, loosely referred to as "disability".

\section{Statistical analysis and interpretation}

This study analysed the burden of malignant neoplasms (cancer) in Ethiopia from the general measurement of disease burden and from the burden of group II (NCD) diseases. The GBD study and GHE approach to estimating all-cause mortality and cause-specific mortality rates by age, sex, and year has been described elsewhere [14]. Causes of death by age, sex, and year for all causes were measured mainly using cause of death ensemble modelling (CODEm), which models different statistics and estimates outcomes based on the performance of fitted models $[15,16]$. DALY was measured by summing years of life lost (YLL) due to premature mortality and years lived with disability (YLD), a measure of non-fatal health loss, in a single metric. YLL was estimated using standard GBD methods whereby each death is multiplied by the normative standard life expectancy at each age. YLD was estimated using sequelae prevalence and disability weights derived from population-based surveys. For most sequelae, the GBD 2016 study used a Bayesian meta-regression method, DisMod-MR 2.1, designed to address key limitations in descriptive epidemiological data, including missing data, inconsistency, and large methodological variation between data sources [14].

\section{Results}

Deaths from cancer for both sexes and all age groups in Ethiopia

Cancers caused an estimated 50,913.5 (95\% CI: 36092.1-73018.8) deaths among all age and both gender groups in 2016. Death from cancer has also contributed to $18.5 \%(50,913.5 / 274,998.8)$ of deaths from noncommunicable diseases and 7.3\% (50,913.5/700,108.8) of the total death reported by the same year. The number of deaths from cancer increased by $47.4 \%$ between 2000 and 2016. By the same year the crude death rate (CDR) related to cancers was estimated to be $49.7 / 100,000$, and the age-standardised death rate (ASDR) was 93.5/100,000 population. Both declined from the 2000 level only by $4.2 \%$ and $9.7 \%$, respectively (Tables 1 and 2).

Crude age-standardised death rate per 100,000 population from cancer in Ethiopia

Among the specific types of cancer, other cancers caused the highest number of deaths, 10,916.3
(95\% CI: 6985.9-16614). While breast cancer with 7653.6 (95\% CI: 4961.7-11508.1) deaths, cervix uteri cancer with 5013.5 (95\% CI: 3197.1-7655.4) deaths, and colon and rectum cancers with 3475.1 (95\% CI: 2116.5-5533.4) deaths ranked second to fourth places. In addition, mortality from leukaemia, lymphomas and myeloma, ovary cancer, trachea and lung cancers, oesophagus cancer, and stomach cancer contributed to significant numbers of deaths reported in 2016.

The crude death rate from cancer declined by $4.2 \%$ from $51.9 / 100,000$ population to $49.7 / 100,000$ population between 2000 and 2016. The most common causes of death remained the same in the two periods. Other cancers caused a CDR of 10.7/100,000 population in 2016 and ranked as the top killer, and followed by breast cancer, cervix and uteri cancer, and colon and rectum cancer. The CDR from cervix uteri cancer, oesophagus cancer, stomach cancer, and testicular cancer declined by $26-40 \%$ whereas death from ovary cancer, pancreas cancer, brain and nervous system cancers, and prostate cancer rose by $20-36 \%$.

Cancer was the highest contributor of age-standardised death by the year 2016. This classification of disease contributed to $16.9 \%(93.5 / 554.7)$ and $9 \%$ (93.5/1048.3) per 100,000 population of ASDR from the non-communicable category and from the total deaths, respectively. Among the specific type of cancers, other cancers, breast cancer, cervix uteri cancer, and colon and rectum cancers caused the highest ASDR with a rate of 18.9/100,000, 13.4/100,000, 9.9/100,000, and 6.7/100,000 population, respectively, by the year 2016 .

Although the ASDR from testicular cancer, stomach cancer, oesophagus cancer, and cervical cancer declined between 29 and 43\%, death from ovary cancer, brain and nervous system cancer, kidney cancer, and pancreas cancer increased by $12-27.5 \%$ between 2000 and 2016. The overall cancer-related mortality declined by $9.7 \%$ during the specified period of time (Table 2 ).

\section{Disability-adjusted life years lost from cancer in Ethiopia}

Disability-adjusted life years (DALY) lost due to cancers among all ages was 2,012,500 DALYs in 2016, which was an increase of $45.1 \%$ from the 2000 value of $1,386,700$ DALYs. It accounted for $12.7 \%$ $(2,012,500 / 15,849,800)$ of national NCD-related DALYs and $4.3 \%(2,012,500 / 46,507,400)$ of the national total DALYs. The top five causes of cancer-related deaths were other cancers, breast cancer, cervix uteri cancer, leukaemia, and lymphomas with 462,600, 327,000, $180,300,161,100$, and 133,400 DALYs, respectively.

Since 2000, DALYs due to all specific types of cancer increased substantially, except for stomach cancer (Table 3). DALYs from ovary cancer doubled between 2000 and 2016. Similarly, DALYs from prostate cancer, brain and nervous system cancers, pancreas cancer, 
Table 1. Number of deaths from cancer for both sexes and all age groups in Ethiopia from 2000 to 2016

\begin{tabular}{|c|c|c|c|c|c|c|c|}
\hline \multirow[t]{2}{*}{ Cause of death } & \multicolumn{3}{|c|}{ Number of deaths in 2000} & \multicolumn{3}{|c|}{ Number of deaths in 2016} & \multirow{2}{*}{$\begin{array}{c}\% \\
\text { change }\end{array}$} \\
\hline & Value & $95 \% \mathrm{LL}$ & $95 \%$ UL & Value & $95 \% \mathrm{LL}$ & $95 \%$ UL & \\
\hline All causes & 981955.9 & 867049.4 & 1107745.6 & 700108.8 & 588955.7 & 831398.4 & -28.7 \\
\hline Non-communicable diseases & 199299.9 & 158916.3 & 248625.1 & 274998.8 & 211290.2 & 362882.1 & 38.0 \\
\hline Cancer & 34534.5 & 25677.2 & 46261.7 & 50913.5 & 36092.1 & 73018.8 & 47.4 \\
\hline Mouth and oropharynx cancers & 870.6 & 542.0 & 1344.9 & 1373.1 & 798.5 & 2275.8 & 57.7 \\
\hline Oesophagus cancer & 1453.3 & 929.2 & 2191.6 & 1651.1 & 972.8 & 2706.9 & 13.6 \\
\hline Stomach cancer & 1490.7 & 949.5 & 2255.6 & 1511.1 & 883.1 & 2494.1 & 1.4 \\
\hline Colon and rectum cancers & 2370.5 & 1538.3 & 3525.7 & 3475.1 & 2116.5 & 5533.4 & 46.6 \\
\hline Liver cancer & 654.8 & 402.6 & 1022.6 & 1102.1 & 633.6 & 1844.5 & 68.3 \\
\hline Pancreas cancer & 297.2 & 176.0 & 479.5 & 552.6 & 305.8 & 954.4 & 85.9 \\
\hline Trachea, lung cancers & 1005.7 & 630.0 & 1545.0 & 1681.9 & 988.4 & 2762.8 & 67.2 \\
\hline Melanoma and skin cancers & 139.3 & 79.4 & 231.9 & 231.4 & 121.6 & 416.1 & 66.1 \\
\hline Breast cancer & 5184.9 & 3547.7 & 7332.7 & 7653.6 & 4961.7 & 11508.1 & 47.6 \\
\hline Cervix uteri cancer & 4427.3 & 3014.5 & 6290.7 & 5013.5 & 3197.1 & 7655.4 & 13.2 \\
\hline Corpus uteri cancer & 183.4 & 109.7 & 293.5 & 246.1 & 135.2 & 427.5 & 34.2 \\
\hline Ovary cancer & 1200.2 & 779.2 & 1784.4 & 2511.2 & 1554.6 & 3940.3 & 109.2 \\
\hline Prostate cancer & 702.9 & 446.6 & 1065.9 & 1384.4 & 833.8 & 2226.2 & 97.0 \\
\hline Testicular cancer & 82.6 & 47.4 & 136.7 & 77.1 & 39.3 & 141.8 & -6.6 \\
\hline Kidney cancer & 741.4 & 459.0 & 1151.1 & 1282.4 & 743.9 & 2130.1 & 73.0 \\
\hline Bladder cancer & 617.5 & 379.5 & 965.0 & 937.4 & 536.0 & 1576.2 & 51.8 \\
\hline Brain and NS system cancers & 264.2 & 156.0 & 427.2 & 508.9 & 281.4 & 879.3 & 92.7 \\
\hline Gallbladder and biliary cancer & 445.2 & 272.1 & 699.4 & 587.3 & 330.2 & 1001.6 & 31.9 \\
\hline Larynx cancer & 137.4 & 78.7 & 228.0 & 180.5 & 94.3 & 325.9 & 31.3 \\
\hline Thyroid cancer & 1045.1 & 658.0 & 1598.4 & 1390.0 & 810.6 & 2298.5 & 33.0 \\
\hline Lymphomas \& myeloma & 1897.3 & 1220.6 & 2844.6 & 3098.6 & 1877.3 & 4957.1 & 63.3 \\
\hline Leukaemia & 2317.4 & 1502.7 & 3449.4 & 3473.7 & 2115.3 & 5531.9 & 49.9 \\
\hline Other cancers & 6937.3 & 4684.3 & 9937.3 & 10916.3 & 6985.9 & 16614.0 & 57.4 \\
\hline
\end{tabular}

LL-lower limit, UL- upper limit.

liver cancer, kidney cancer, trachea, bronchus, lung cancers, lymphomas, multiple myeloma, mouth and oropharynx cancers, and other cancers increased by $55-94 \%$ within the same period.

\section{Discussion}

The burden of cancer in terms of mortality and disability-adjusted life years was measured among all ages and genders for Ethiopia between 2000 and 2016 by using aggregates of data from the global health estimates. The number of deaths from cancer increased by $47.4 \%$ between 2000 and 2016 . However, the crude death rate and age-standardised death rate declined by $4.2 \%$ and $9.7 \%$, respectively, within the specified period. The change in the overall cancer mortality may highlight the increasing incidence of cancer and contribution of factors leading to increased density of cancer and other non-communicable diseases such as: ageing, nutritional transition, environmental change, and population growth [5, 9-13].

The contribution of cancer to the total mortality and mortality specific to non-communicable diseases increased tremendously. In 2016 cancer contributed to $18.5 \%$ of deaths from non-communicable diseases and $7.3 \%$ of the total deaths reported in Ethiopia. It indicates a tremendous increment from the 2014 report, in which cancer contributed $6 \%$ of all deaths reported in Ethiopia. Studies showed that the role of non-communicable diseases and cancer could significantly increase in the epidemiology of disease burden, particularly in Africa, where the burden of NCD is increasing by $27 \%$, surpassing the global average of $17 \%[5,11,15-17]$.

Unless effective measures are taken the burden of cancer in Ethiopia as well as Africa could exceed all combined communicable diseases as the most com- 
Table 2. Crude and ASDR/100,000 population from cancer for sex and all age groups from 2000 to 2016

\begin{tabular}{|c|c|c|c|c|c|c|}
\hline \multirow[t]{2}{*}{ Cause by group } & \multicolumn{3}{|c|}{ CDR } & \multicolumn{3}{|c|}{ ASDR } \\
\hline & 2000 & 2016 & \%Change & 2000 & 2016 & \%Change \\
\hline All causes & 1475.8 & 683.7 & -53.7 & 1816.7 & 1048.3 & -42.3 \\
\hline Non-communicable diseases & 299.5 & 268.5 & -10.3 & 634.3 & 554.7 & -12.5 \\
\hline Cancer & 51.9 & 49.7 & -4.2 & 103.6 & 93.5 & -9.7 \\
\hline Mouth and oropharynx cancers & 1.3 & 1.3 & 0 & 2.6 & 2.5 & -5.7 \\
\hline Oesophagus cancer & 2.2 & 1.6 & -26.2 & 4.8 & 3.4 & -29.3 \\
\hline Stomach cancer & 2.2 & 1.5 & -34.1 & 4.8 & 3.0 & -37.1 \\
\hline Colon and rectum cancers & 3.6 & 3.4 & -4.7 & 7.4 & 6.7 & -10.1 \\
\hline Liver cancer & 1.0 & 1.1 & 9.4 & 2.0 & 2.1 & 3.4 \\
\hline Pancreas cancer & 0.4 & 0.5 & 20.8 & 1.0 & 1.2 & 12.2 \\
\hline Trachea, bronchus, lung cancers & 1.5 & 1.6 & 8.7 & 3.2 & 3.3 & 5.2 \\
\hline Melanoma and other skin cancers & 0.2 & 0.2 & 7.9 & 0.5 & 0.5 & -1.5 \\
\hline Breast cancer & 7.8 & 7.5 & -4.1 & 14.8 & 13.4 & -9.5 \\
\hline Cervix uteri cancer & 6.7 & 4.9 & -26.4 & 13.9 & 9.9 & -29.1 \\
\hline Corpus uteri cancer & 0.3 & 0.2 & -12.8 & 0.6 & 0.5 & -17.9 \\
\hline Ovary cancer & 1.8 & 2.5 & 35.9 & 3.6 & 4.6 & 27.5 \\
\hline Prostate cancer & 1.1 & 1.4 & 28.0 & 3.0 & 3.2 & 7.5 \\
\hline Testicular cancer & 0.1 & 0.1 & -39.3 & 0.2 & 0.1 & -42.9 \\
\hline Kidney cancer & 1.1 & 1.3 & 12.4 & 1.6 & 1.8 & 16.1 \\
\hline Bladder cancer & 0.9 & 0.9 & -1.4 & 2.2 & 2.0 & -8.9 \\
\hline Brain and nervous system cancers & 0.4 & 0.5 & 25.2 & 0.7 & 0.9 & 18.6 \\
\hline Gallbladder and biliary tract cancer & 0.7 & 0.6 & -14.3 & 1.3 & 1.1 & -18.4 \\
\hline Larynx cancer & 0.2 & 0.2 & -14.7 & 0.5 & 0.4 & -19.8 \\
\hline Thyroid cancer & 1.6 & 1.4 & -13.6 & 3.6 & 3.0 & -18.5 \\
\hline Lymphomas, multiple myeloma & 2.9 & 3.0 & 6.1 & 5.3 & 5.4 & 2.4 \\
\hline Leukaemia & 3.5 & 3.4 & -2.6 & 6.0 & 5.6 & -5.9 \\
\hline Other cancers & 10.4 & 10.7 & 2.2 & 19.6 & 18.9 & -3.7 \\
\hline
\end{tabular}

$C D R$ - crude death rate, $A S D R$ - age-standardised death rate, NCD - non-communicable disease.

mon cause of death in the near future $[2,5]$. This implies that NCDs, like cancer, represent a leading threat to health, the economy, and overall human development in the country. This is because in lower income countries the increase in the relative burden from NCDs and the decrease in communicable disease burden are occurring more rapidly than in high-income countries. In particular, the burden of cardiovascular diseases and cancer is rapidly increasing [16-19]. The research conducted in India also showed this, where the number of new cases and deaths due to cancer doubled in 26 years [15].

Although the epidemiological shift observed in most developing countries plays a major role in the burden of cancer [15-18], interventions designed to address non-communicable diseases, particularly cancer, were poorly implemented in developing countries. As yet, the Ethiopian government has not formulated a preventive strategy to overcome the burden of cancer and non-communicable diseases at large. Also, global interventions were designed in the previous millennium, and sustainable development goals were targeted on infectious diseases, maternal and child health, and nutritional problems, and less emphasis was given to cancer and other NCDs [5, 14-19].

Among the specific types of cancers, other cancers, breast cancer, cervix uteri cancer, colon and rectum cancers, and leukaemia caused the highest number of deaths and ranked as the five top causes of age-standardised death from cancer. In addition, mortality 
Table 3. DALY from cancer in thousands for both sexes and all age groups in Ethiopia from 2000 to 2016

\begin{tabular}{|c|c|c|c|}
\hline Causes of DALY & 2000 & 2016 & $\begin{array}{c}\% \\
\text { change }\end{array}$ \\
\hline All causes & 71354.0 & 46507.4 & -34.8 \\
\hline $\begin{array}{l}\text { Non-communicable } \\
\text { diseases }\end{array}$ & 12053.5 & 15849.8 & 31.5 \\
\hline Cancer & 1386.7 & 2012.5 & 45.1 \\
\hline $\begin{array}{l}\text { Mouth and oropharynx } \\
\text { cancers }\end{array}$ & 35.5 & 55.3 & 55.9 \\
\hline Oesophagus cancer & 47.8 & 53.0 & 11.0 \\
\hline Stomach cancer & 52.6 & 51.6 & -1.7 \\
\hline $\begin{array}{l}\text { Colon and rectum } \\
\text { cancers }\end{array}$ & 88.6 & 127.8 & 44.3 \\
\hline Liver cancer & 25.1 & 42.4 & 68.9 \\
\hline Pancreas cancer & 9.6 & 17.7 & 83.8 \\
\hline $\begin{array}{l}\text { Trachea, bronchus, lung } \\
\text { cancers }\end{array}$ & 35.6 & 58.6 & 64.7 \\
\hline Breast cancer & 226.9 & 327.0 & 44.2 \\
\hline Cervix uteri cancer & 163.2 & 180.3 & 10.4 \\
\hline Ovary cancer & 47.2 & 97.6 & 107.0 \\
\hline Prostate cancer & 18.2 & 35.3 & 94.2 \\
\hline Kidney cancer & 43.3 & 71.3 & 64.8 \\
\hline Bladder cancer & 18.2 & 26.6 & 46.3 \\
\hline $\begin{array}{l}\text { Brain and nervous } \\
\text { system cancers }\end{array}$ & 11.9 & 22.4 & 88.5 \\
\hline $\begin{array}{l}\text { Gallbladder and biliary } \\
\text { tract cancer }\end{array}$ & 17.3 & 22.8 & 31.9 \\
\hline Thyroid cancer & 29.0 & 37.5 & 29.3 \\
\hline $\begin{array}{l}\text { Lymphomas, multiple } \\
\text { myeloma }\end{array}$ & 84.1 & 133.4 & 58.6 \\
\hline Leukaemia & 112.1 & 161.1 & 43.7 \\
\hline Other cancers & 298.6 & 462.6 & 54.9 \\
\hline
\end{tabular}

$D A L Y$ - disability-adjusted life years lost.

from lymphomas and myeloma, ovary cancer, trachea and lung cancers, oesophagus cancer, and stomach cancer contributed to a significant number of deaths reported in 2016. It is nearly similar to the global epidemiology, in which breast, cervical, colorectal, and stomach cancer are the leading causes of mortality in most countries $[5,15]$.

In 2016 around 2,012,500 DALYs were lost due to cancer among all age groups and genders in Ethiopia. It increased by $45.1 \%$ from the 2000 record of $1,386,700$ DALYs and accounted for $12.7 \%$ of national NCD-related DALYs and $4.3 \%$ of the national total DALYs. The percentage contribution of cancer-related DALYs in this report is slightly lower than the global average and reports of India [14], while it is nearly the same as the average value of sub-Saharan countries [5]. In line with the global epidemiology, the major contributors of cancer-related DALYs were other cancers, breast cancer, cervix uteri cancer, leukaemia, and lymphomas.

DALYs due to all specific types of cancer increased substantially, except for stomach cancer. DALYs from ovary cancer doubled, while DALYs from prostate cancer, brain and nervous system cancers, pancreas cancer, liver cancer, kidney cancer, trachea, bronchus, lung cancers, lymphomas, multiple myeloma, mouth and oropharynx cancers, and other cancers increased by $55-94 \%$ within the same period. This may be a result of the increased burden of smoking and alcohol consumption - major risk factors related to most cancer cases - along with other predisposing factors and the absence of good medical facilities [5, 14-18].

This research is based on secondary data analysis, and the primary data was based on model estimations; therefore, the potential biases related to this and the issue of validity are there. Moreover, the forecasted values from the trend may change over time due to a change in intervention programmes, and this content affects the reliability of the estimate. Hence, all interpretations should consider these limitations.

\section{Conclusions and recommendations}

Cancer contributed to $18.5 \%$ of deaths from noncommunicable diseases and $7.3 \%$ of the total number of deaths. It was also responsible for $16.9 \%$ and $9 \%$ of ASDRs from the non-communicable category and from the total deaths and $12.7 \%$ of national NCDrelated DALYs and $4.3 \%$ of the national total DALYs, respectively. The number of death and DALYs from cancer increased by $47.4 \%$ and $45.1 \%$, respectively, whereas CDR and ASDR from cancer declined by $4.2 \%$ and $9.7 \%$, respectively. Other cancers, breast cancer, cervix uteri cancer, colon and rectum cancers, and leukaemia caused the highest number of deaths and ranked as the top five causes of age-standardised death rates from cancer. While other cancer, breast cancer, cervix uteri cancer, leukaemia, and lymphomas were the five top causes of DALYs lost due to cancer in Ethiopia by the year 2016.

Therefore, the existing disease prevention strategies should incorporate NCD prevention strategies with particular emphasis on cancer screening, prevention, care, and improving the cancer registration system.

\section{Acknowledgments}

For all who ever assisted us in this project.

\section{Conflict of interest}

The authors declare no conflict of interest. 


\section{Reference}

1. ECA. What is a Cancer? Available at: http://yeeca.org/

2. Cordella M, Poiani A. Behavioural Oncology. Psychological, Communicative, and Social Dimensions. Springer-Verlag, New York 2014.

3. Ytayew SA, Shibabaw ME, Vagrecha Y. Effectiveness of existential group therapy for treatment of psychological problem of cervical cancer patients. Innovare J Soc Sci 2015; 3: 5-9.

4. Jemal A, Bray F, Center MM, Ferlay J, Ward E, Forman D. Global cancer statistics. CA Cancer J Clin 2011; 61: 69-90.

5. Global Burden of Disease Cancer Collaboration. Global, regional, and national cancer incidence, mortality, years of life lost, years lived with disability, and disability adjusted life-years for 32 cancer groups, 1990 to 2015: a systematic analysis for the Global Burden of Disease Study. JAMA Oncol 2017; 3: 534-548.

6. WHO. All cancers. 2018. Available at: http://gco.iarc.fr/today/data/factsheets/cancers/39-All-cancers-fact-sheet.pdf

7. WHO. Latest global cancer data. Press release $\mathrm{N}^{\circ} 263$. 2018. Available at: https://www.who.int/cancer/PRGlobocanFinal.pdf

8. WHO. Estimated number of incident cases from 2018 to 2040, all cancers, both sexes, all ages. Available at: http:// gco.iarc.fr/

9. Jennifer D, Cathyryne K, Dan M, Miriam M, Anne N, Olufunmilayo I. et al. Africa's Emerging Cancer Crisis: A Call to Action. 2017.

10. Jemal A, Bray F, Forman D, o’Brien M, Ferlay J, Center M, Maxwell Parkin D. Cancer burden in Africa and opportunities for prevention. Cancer 2012; 118: 4372-4384.

11. FMoH. National cancer control plan of Ethiopia 20162020. FMO, 2016. Available at: https://www.iccp-portal. org/sites/default/files/plans/NCCP\%20Ethiopia\%20 Final\%20261015.pdf

12. GLOBOCAN. Cancer observation in Ethiopia. 2019. Available at: http://gco.iarc.fr/today/data/factsheets/populations/231-ethiopia-fact-sheets.pdf

13. Woldeamanuel YW, Girma B, Teklu AM. Cancer in Ethiopia 2013; 14: 289-290.

14. WHO methods and data sources for global burden of disease estimates 2000-2016 (Global Health Estimates Technical Paper WHO/HIS/IER/GHE/2018.4).

15. India State-Level Disease Burden Initiative Cancer Collaborators. The burden of cancers and their variations across the states of India: the Global Burden of Disease Study 1990-2016. Lancet Oncol 2018; 19: 1289-1306.

16. Misganaw A, Haregu TN, Deribe K, Tessema GA, Deribew A, Melaku YA, Amare AT, Abera SF, Gedefaw M, Dessalegn M, Lakew Y, Bekele T, Mohammed M, Yirsaw BD, Damtew SA, Krohn KJ, Achoki T, Blore J, Assefa Y, Naghavi M. National mortality burden due to communicable, non-communicable, and other diseases in Ethiopia, 19902015: findings from the Global Burden of Disease Study 2015. Popul Health Metr 2017; 15: 29.

17. Misganaw A, Mariam DH, Ali A, Araya T. Epidemiology of major non-communicable diseases in ethiopia: a systematic review. J Health Popul Nutr 2014; 32: 1-13.

18. Global Health Estimates 2016. Deaths by cause, age and sex, by country and by region, 2000-2016. Geneva: World Health Organization; 2018 (https://www.who.int/healthinfo/global_burden_disease/estimates/en/index1.html)
19. Global Health Estimates 2016. Global, regional, and national disability-adjusted life-years (DALYs) for 333 diseases and injuries and healthy life expectancy (HALE) for 195 countries and territories, 1990-2016: a systematic analysis for the Global Burden of Disease Study 2016.

\section{Address for correspondence:}

Assist. Prof. Mulugeta Shegaze

Department of Public Health

School of Public Health

College of Medicine and Health Sciences

Arba Minch University

Arba Minch Town, Ethiopia

E-mail: mulsheg@yahoo.com 